\title{
Grundtvigs krise i foråret 1844. Forholdet mellem prædiken og salme med henblik på "Sov sødt, Barnlille"
}

\section{Af Christian Thodberg}

I forbindelse med udgivelsen af Grundtvigs prædikener i 1840'erne er nye enkeltheder om Grundtvigs depression i foråret 1844 kommet frem. Hans kræfter svigtede, og man kan tydeligt se hans tilstand $\mathrm{i}$ den forandrede håndskrift; han måtte have bistand til at passe sit embede, hvilket giver anledning til en urimelig konflikt med biskop Mynster. Af særlig betydning er hans sidste prædiken 1. maj 1844, hvor han tager afsked med sin menighed i Vartov før sit sammenbrud, og det farver tilblivelsen af "Sov sødt, Barnlille" under hans følgende rekreationsrejse og besøg hos præstevennerne på Sjælland og giver et stærkt indtryk af den støtte, han modtager fra sine tilhængere. De utrykte breve til og fra Grundtvig marts - juni 1844 er gengivet i denne udgave af Grundtvig-Studier (se s. 72 ff.) og sidehenvisningerne i det følgende henviser dertil.

I løbet af foråret 1844 ramtes Grundtvig af en depression, efter alt at dømme fremkaldt af et anfald af făresyge, en sygdom, der foruden hævelser kan ytre sig i en hjernebetændelse. Sygdommen havde formentlig et længere forløb begyndende med fysiske vanskeligheder og sluttende med psykiske lidelser. Hans omgangskreds har vidst det og fulgt udviklingen i hans tilstand, og i et brev lørdag 30. marts 1844 ønskede Gunni Busck ham god bedring inden påsken, og da Bertel Thorvaldsens begravelse netop på denne dag fandt sted fra Vor Frue Kirke, bemærker Busck: “...jeg siger i mit Hjerte: Gud lade ham i Jesu Navn have det godt, hvor han er vandret hen, saa veed jeg han blæser ad alle denne Verdens Ceremonier" (Fasc. 460, se også side 74)

Thorvaldsen døde som bekendt i Det kgl. Teater den 24. marts, men så sent som den 23. marts havde man fejret Thorvaldsen i Det skandinaviske Selskab, og Grundtvig havde til den lejlighed skrevet en sang ("Nordens Konst"), der blev afsunget (PS VI, 481-82). Buscks bemærkninger om Thorvaldsens liv $\mathrm{i}$ det hinsides er formentlig tidstypiske: Thorvaldsen havde jo erklæret sig som ikke-kristen, men kunne man tænke sig, at en sådan stor åndspersonlighed skulle gå fortabt? Grundtvig tog sagen alvorligt, og i anledning af Thorvaldsens død skrev han endnu et digt "Albert Thorvaldsen", der først blev trykt senere. ${ }^{1}$

Digtet er interessant af to grunde: for det første gør Grundtvig sig store anstrengelser for at gøre Thorvaldsen kristen. Men han havde 
kun kendt den falske kristendom i sin ungdom i det rationalistiske København og siden i den "lummervarme" udgave i det katolske Rom (strofe 11). ${ }^{2}$ Som hedning hørte han til "lysalferne", der stod Gud nær (strofe 12). Digtet til Thorvaldsen svarer i sit indhold og intention til den interesse for forholdet menneske først/kristen så, der dukkede op påny fra og med prædikenen på nytårsdag 1844 ligesom i prædikenerne sidst i 1830 'erne.

For det andet offentliggjorde Grundtvig først sit digt i tidsskriftet Danskeren, og i denne første trykte version i 1848 tilføjede han i en note: "Skiøndt dette Vers [digt], skrevet i meget syg Tilstand, har været forlagt og er blevet forligget, giver jeg det dog, som jeg finder det, da hvis jeg har andet om Sagen at melde, det helst maa staae for sig selv". At digtet er skrevet i en tilstand af dyb depression, fremgår af digtet, hvor han skulle forsvare, at Thorvaldsen savner troen (strofe 16):

Jeg korser mig for lede "Satan" kun,

Og ei for Mennesker, som mine Lige,

Jeg selv var Hedning, men dog ingen Hund,

Og Skriftemaalet mit i Sandheds Rige,

Det lyder saa: det randt mig nys ihu,

At der er meget Hedenskab hos mig endnu!

Det er ikke uden grund, at man kommer til at overveje, om den afstand til kristendommen, som Grundtvig her markerer, har noget med hans egen samtidige depression at gøre.

Grundtvig havde formentlig været til stede ved begravelsen, men han prædikede ikke den følgende palmesøndag - den 31. marts 1844 (se nedenfor, note 3 ).

Skærtorsdag stod Grundtvig selv på prædikestolen ved højmessen; hans prædiken var en johannæisk inspireret udlægning af nadveren ud fra Joh 6. Han prædikede også langfredag, men prædikenen tåler ikke sammenligning med langfredagsprædikenen fra 1843, men han taler om døden som den sidste fjende, som man skal spotte med ordene (1 Kor 15,55-56): "Død, Hvor er din Braad? Helvede, hvor er din Seier, lovet være Gud, som har givet os Seieren ved Vorherre Jesum Christum!" - hovedordene i digtet fra 1811 til Sibbern i skildringen af hans depression på vejen til Udby den 31. maj 1811. Grundtvig glemte intet. I sin nye depression mindedes han 1811 !

Prædikenen på påskedag 1844 er mod sædvane nedstemt. Mens Grundtvig stedse fremhæver apostlenes påskevidnesbyrd, siger han, at den påskeprædiken, der er frembåret af Helligånden alene, er langt mere værd. Sagt på en anden måde: apostlenes vidnesbyrd om opstandelsen er en prædiken for menigheden, mens prædikenen af 
Helligånden er for den enkelte. Kan det tænkes, at Grundtvig her først og fremmest prædiker for sig selv og sin egen dødsangst?

Der kan ikke være tvivl om, at Grundtvigs sygdom efterhånden var almindelig kendt $\mathrm{i}$ København. Allerede før påske skrev blandt andet Dronning Caroline Amalie næsten spøgende til Grundtvig: "Hvor inderlig beklager jeg Deres Upasselighed! Faaresyge, hvilken Sygdom og det for Dem!" (Fasc. 450, jf. s. 72 ). Grundtvigs venner var urolige for, hvordan det skulle gå ham.

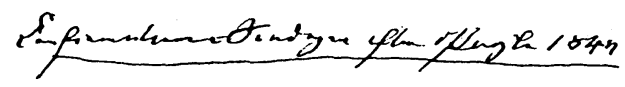

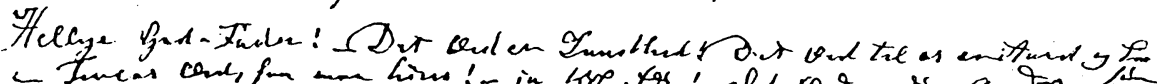

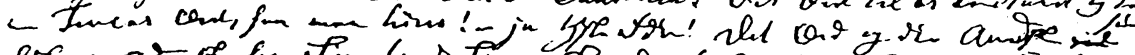

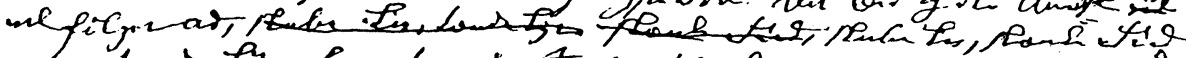

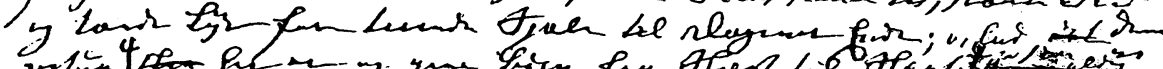

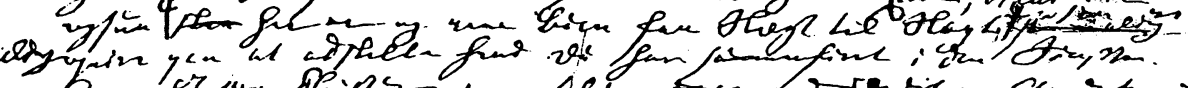

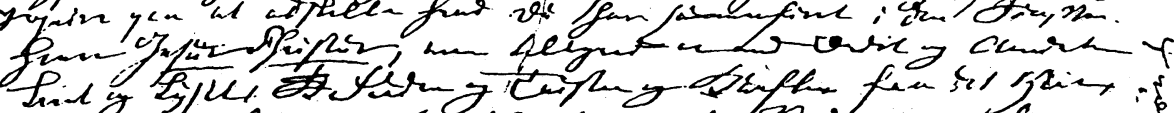

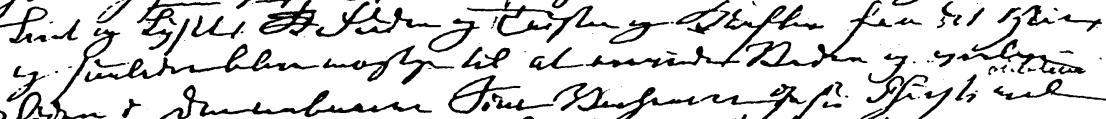

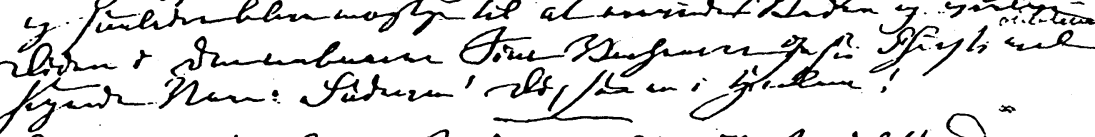

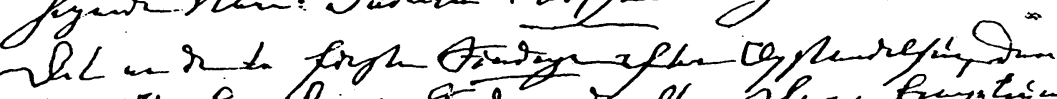

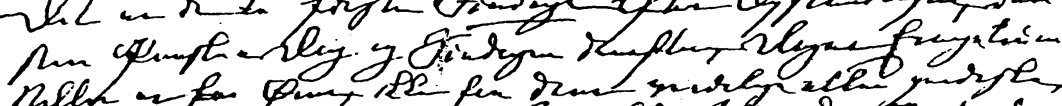

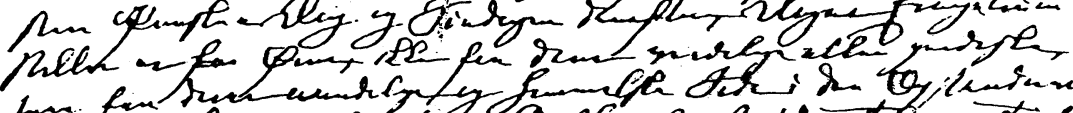

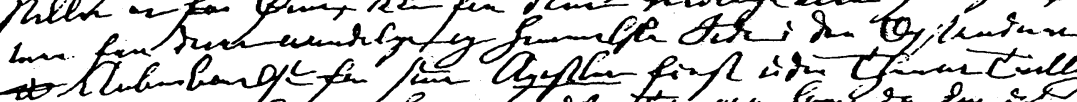

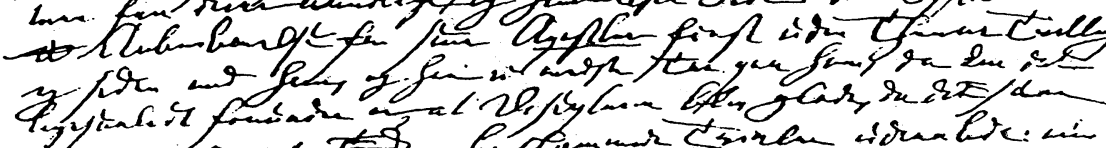

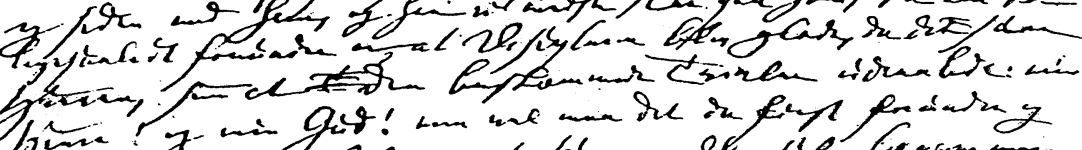

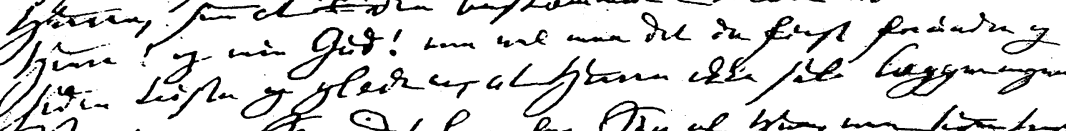

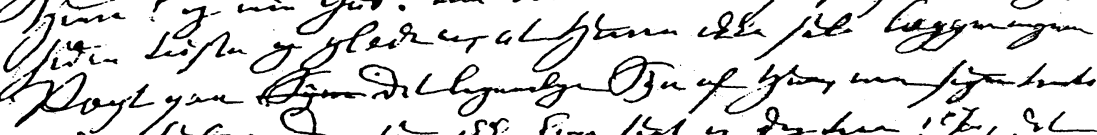

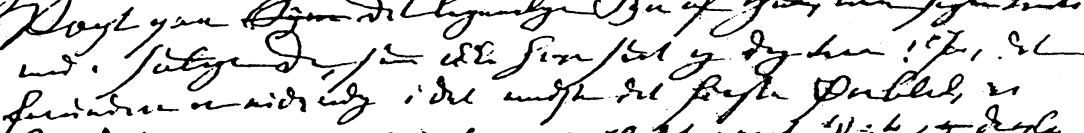

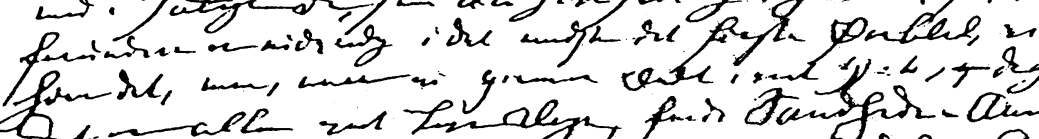

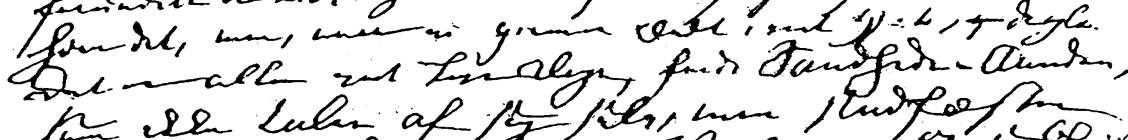

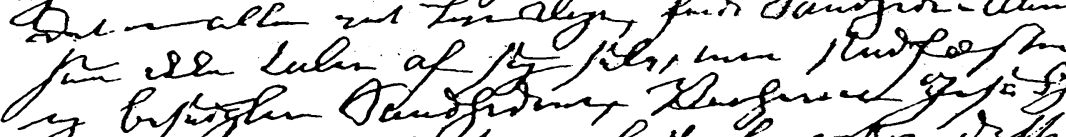

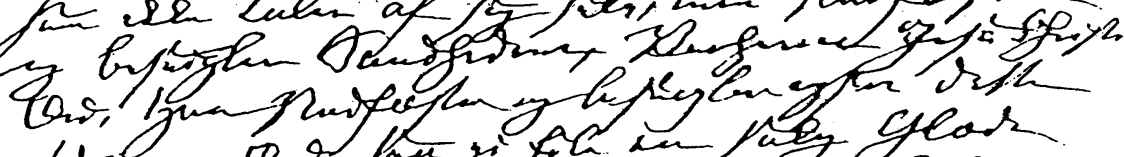

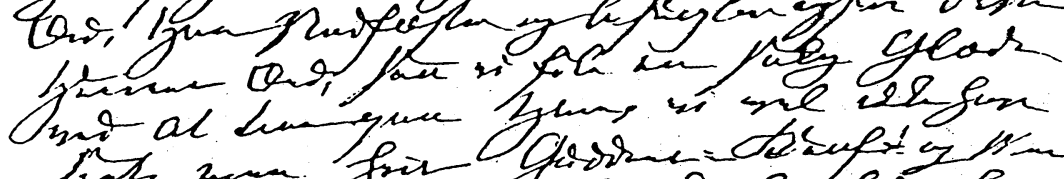

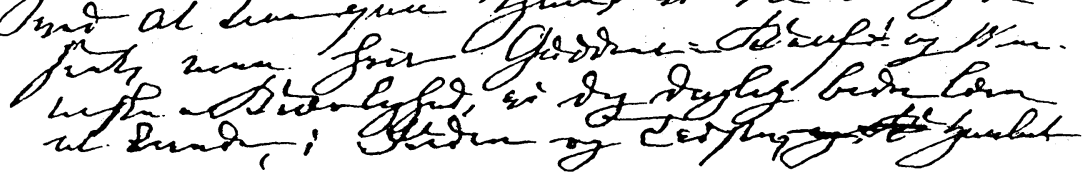


Grundtvigs krise i foråret 1844

41

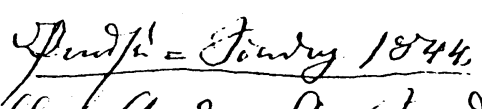

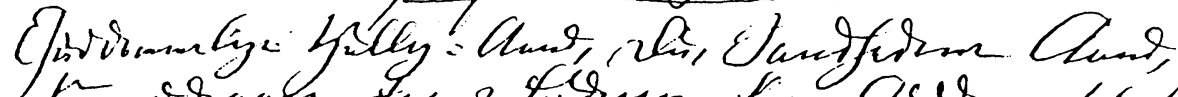

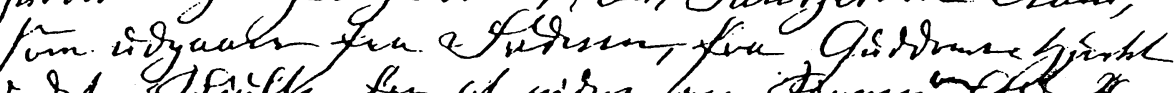

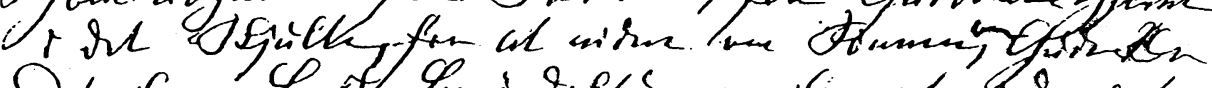

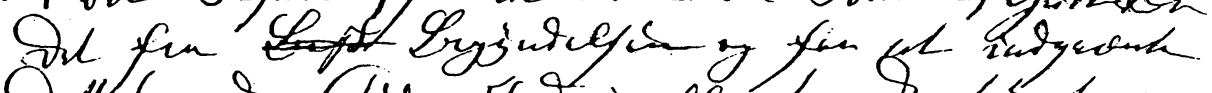

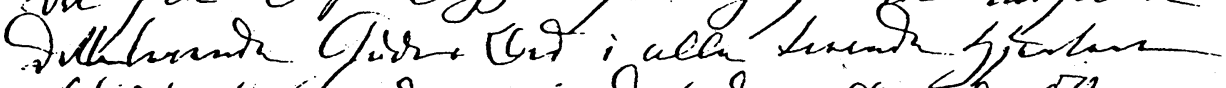

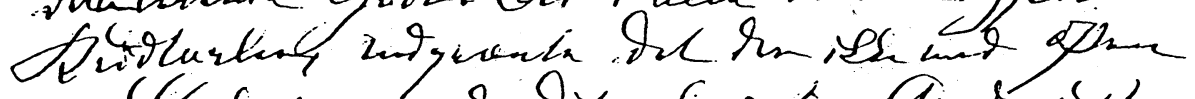

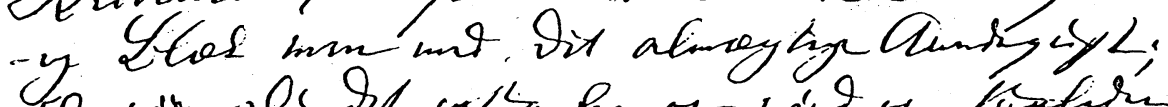

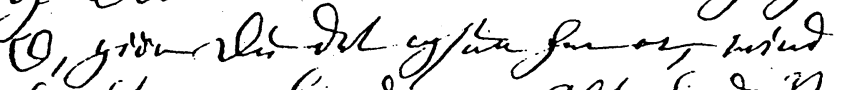

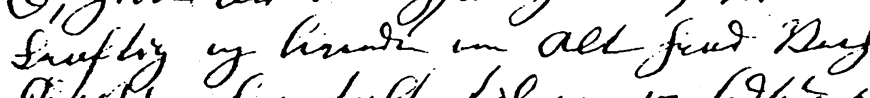

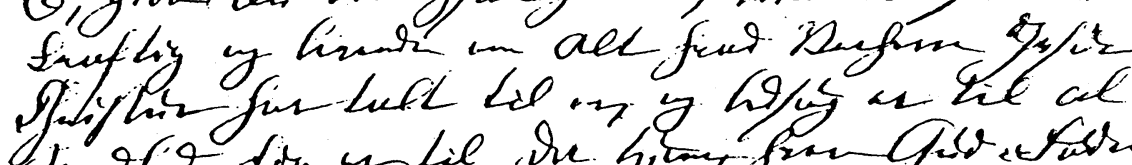

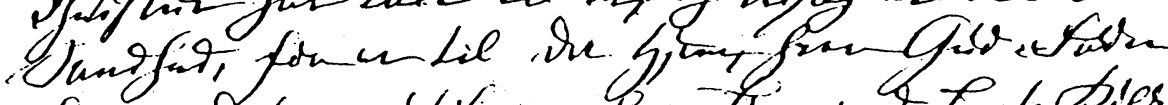

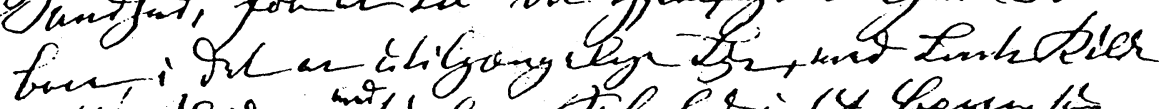

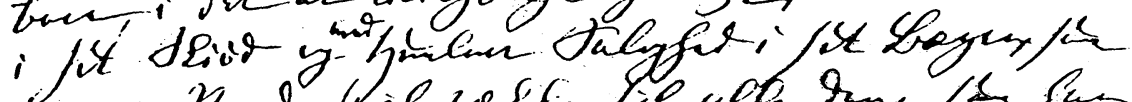

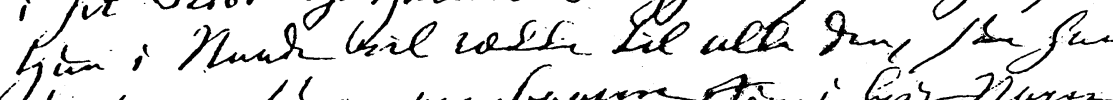

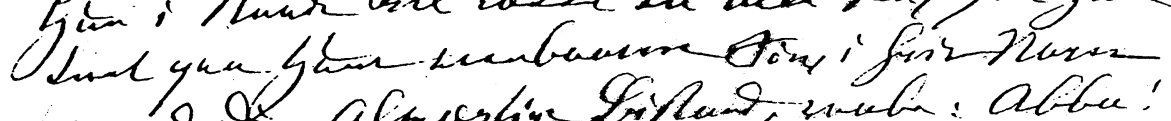

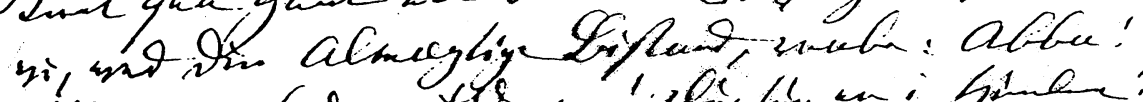

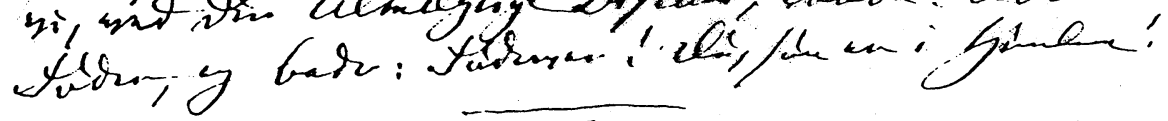

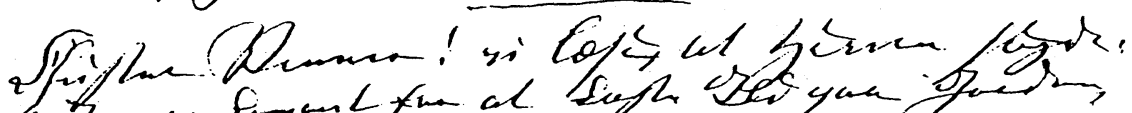

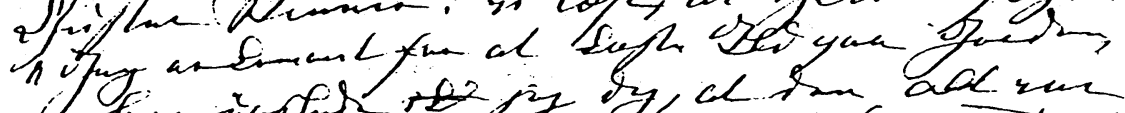

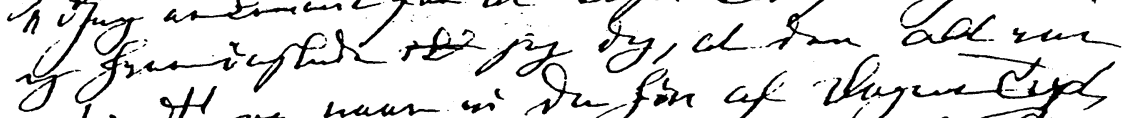

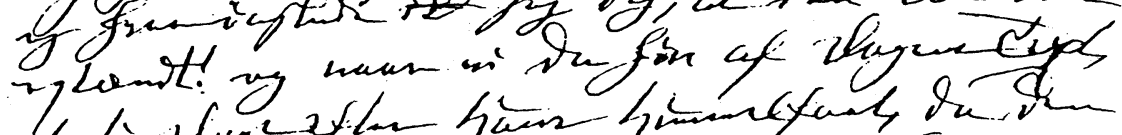

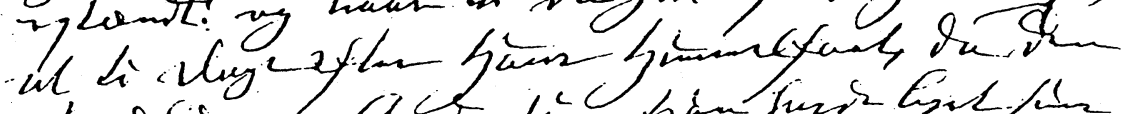

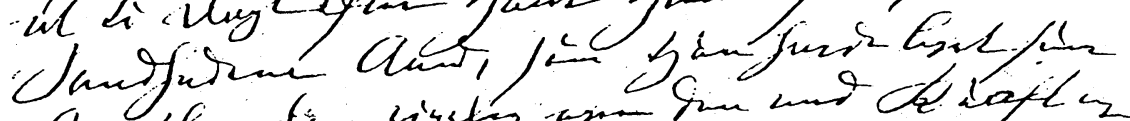

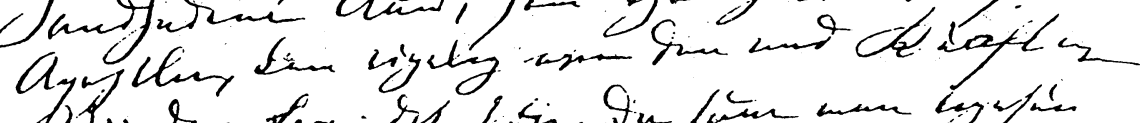

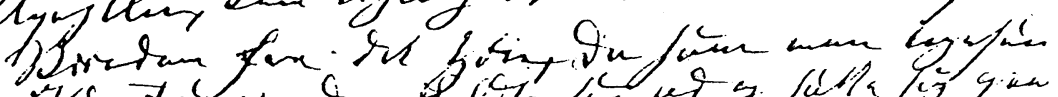

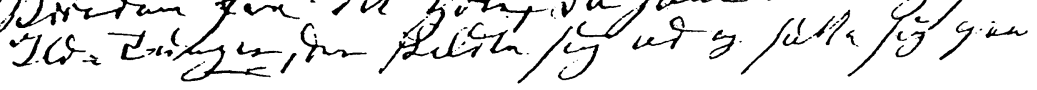

Grundtvigs nedstemthed i marts-maj 1844 kan tydeligt ses på hans håndskrift i prædikenmanuskripterne; skriften bliver mindre og mere og mere forkrampet. Højdepunktet er manuskriptet til prædikenen på 1. søndag efter påske. Men allerede efter hjemkomsten efter rekreationsrejsen i den første prædiken på pinsedag 1844 har Grundtvigs skrift genvundet sin sædvanlige karakter svarende til, at han for eksempel i sine breve fra den samme tid giver udtryk for, at han har overvundet sin depression og har det bedre end nogensinde. 
På 1. søndag efter påske 1844, “Confirmations-Søndagen efter Paaske 1844" holdt Grundtvig konfirmation, en handling, han formentlig nødig ville aflyse. Han prædikede over dagens evangelium om Jesu åbenbaring for apostlene og den tvivlende Thomas (Joh 20,19-31), en kort og meget mat prædiken.

Grundtvig prædikede ikke ved aftensangen på 1. søndag efter påske 1844. Det faldt biskop J. P. Mynster for brystet, og han bemyndigede stiftsprovst E. C. Tryde til tjenstligt at tage sig af sagen. I Trydes brev til Grundtvig af den 17. april hedder det:

Hans Høiærværdighed Biskoppen har under 15 d. M. tilskrevet mig saaledes:

"I Adresse-Avisen for i Løverdags findes i Prædikant-Listen anmeldt for Vartou Kirke: 'Ingen Aftensang'. I den Anledning maa jeg tjenstligst anmode Deres Høiærværdighed behageligen at ville skaffe mig Oplysning om, efter hvilken Bemyndigelse den anordnede Aftensang denne Søndag er bortfalden."

I Anledning heraf maa jeg anmode Deres Velærværdighed om at meddele mig den af Herr Biskoppen forlangte Oplysning -

Khvn d. 17. April 1844. E. Tryde

Velærværdige

Herr Pastor Grundtvig

R. a. D.! (Fasc. 408, jf. s. 74 ).

Grundtvig svarer Tryde

... om det, naturligviis nærmest for mig stødende og ærgerlige, 'Ingen Aftensang' i Adres-Avisen; men naar denne Sag skulde findes en Undersøgelse værd, maatte den vel begynde paa Adres-Comptoiret, hvis Tankegang ved denne Leilighed jeg ei har kunnet opdage og kan da end mindre give nogen Oplysning om" (Fasc. 408, jf. s. 74 . Jf. $B G$ II, 391).

Denne forklaring slog ikke til. Stiftsprovsten svarede 19. april 1844:

Hvor ugjerne jeg end videre fortrædiger Deres Velærværdighed i Anledning af det tidligere berørte Avertissement i Addresseavisen for afvigte Løverdag, maa jeg dog i Anledning af Deres Yttring i Deres Svarskrivelse, som jeg modtog i Gaar, at Undersøgelsen om hiint Avertissement maatte begynde paa Addresse-Comptoiret, hvis Tankegang ved denne Leilighed De ei havde kunnet opdage og derfor end mindre giver Oplysning om, bemærke, at da Avertissementerne om Prædikanterne indgaae fra Prædikanterne selv og meddeles gjennem Kirkebetjenterne, maa Oplysningen vistnok søges i dette Tilfælde hos Deres Velærværdighed, der da selv maa gaae i Rette med Meddeleren eller Avisens Redacteur. - For at opfylde det mig 
overdragne Hverv maa jeg derfor tjenstligst anmode Dem om, at meddele mig Deres Erklæring om, at Avertissementet er indrykket uden Deres Vidende ved en eller anden Misforstaaelse fra vedkommende Meddeler eller Redactions Side.

Khv. d. 19. April 1844. E.Tryde

Velærværdige Herr Pastor Grundtvig R. a. D.! (Fasc. 408, jf. s. 75 ).

\section{Aitobenbabn tongelig \\ Storesfecomptoirs}

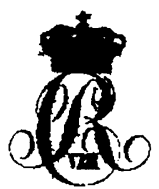

Irythe if Motedecomptoi

\begin{tabular}{|c|c|}
\hline 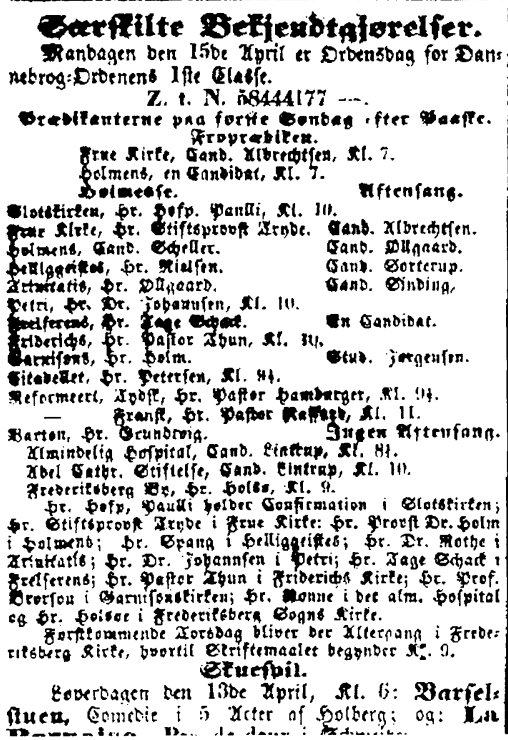 & 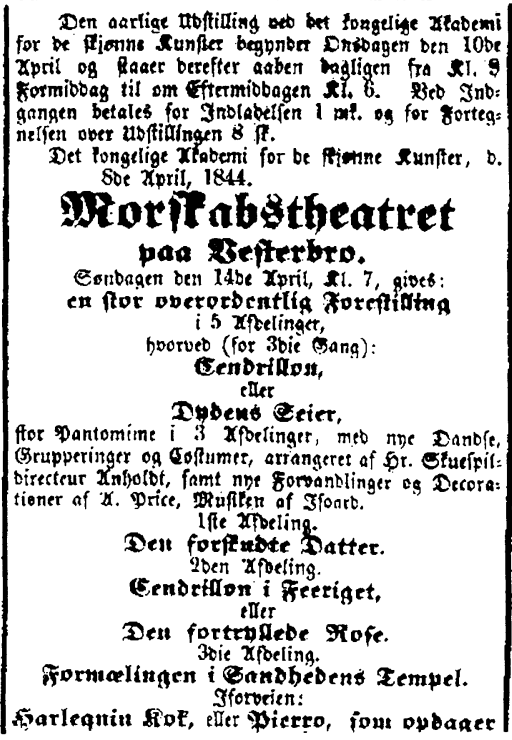 \\
\hline
\end{tabular}

Prædikantlisten i Adresseavisen rummer oplysningerne om gudstjenesterne i Københavns kirker søndag den 14. april. Der står "Vartou, Hr. Grundtvig," og derefter med fed skrift "Ingen Aftensang". Den fede skrift er ejendommelig. Evt. kan den skyldes, at oplysningen skal vække særlig opmærksomhed, eller at oplysningen er sat ind i sidste øjeblik.

\section{Samme dag svarer Grundtvig Tryde:}

Svag som jeg er, saa jeg knap kan røre Pennen, er det vist nok haardt to Gange at kaldes til Regnskab for et tosset Avertissement i Adresavisen, hvori jeg har hverken Lodd eller Deel, thi jeg troede dog ved at fralægge mig det at have gjort Alt hvad man kunde fordre.

Er det derimod Afholdelsen af Aftensang i Vartou en Confirmations-Søndag, da jeg neppe var istand til at forrette Tjeneste, 
man vil kræve mig til Regnskab for, da veed dog vist Deres Højærværdighed, hvad der er hele Byen vitterligt, at i Mands Minde har ingen Præst ved Vartou selv saa omhyggelig besørget Aftensangen, saa en Irettesættelse derfor kunde jeg godt bære, naar jeg ikke, som nu, var saa svag, at den mindste Byrde hviler centnertungt paa mig (Fasc. 408, jf. s. 75. Jf. $B G$ II, 391).

Der er ingen grund til at betvivle Grundtvigs udsagn om, at han ikke havde noget at gøre med aflysningen i avisen; og at han selv har været en flittig aftensangsprædikant, kan man se i Adresseavisen igennem flere år. Men han plejede i øvrigt aldrig selv at holde aftensang på en søndag, hvor han holdt konfirmation. Man kan kun gisne om, hvem der har sat meddelelsen $\mathrm{i}$ avisen. På den anden side: når man ser, $\mathrm{i}$ hvilket omfang Grundtvigs yngre tilhængere vikarierede for ham under sygdomsperioden (fx påskedag og 2. påskedag), er det nærliggende at formode, at en af disse vikarer på 1. søndag efter påske har måttet melde forfald og sat det $i$ avisen.

Stiftsprovst Trydes tjenstlige skrivelser synes trods deres officielle tone at udtrykke, at han handlede efter biskoppens udtrykkelige befaling. Tryde var formand for Københavns gejstlige Konvent, der netop i foråret 1844 havde nedsat en komité med bl. a. prof. Martensen, Grundtvig og Mynsters svigersøn J. H. Paulli til at overveje mulighederne for en helt ny salmebog $\mathrm{i}$ indirekte protest mod biskop Mynsters salmebogstillæg ( $B G$ II, 390).

$\mathrm{Da}$ Grundtvigs sygdom var almindelig kendt i København og af Tryde og Mynster, giver affæren et grelt billede af biskop Mynsters holdning til Grundtvig. ${ }^{3}$

Hvad angår prædikenen på 1. søndag efter påske får man en tydelig fornemmelse af, at dens korte og matte form skyldes Grundtvigs mentale tilstand netop på denne søndag. I den forbindelse kan man godt undre sig over, at Grundtvigs nedstemthed ikke synes at præge hverken de foregående eller de tre følgende prædikener, indtil han rammes af det sammenbrud, som hans venner oplever i maj måned 1844.

Der er ingen grund til i denne sammenhæng at gøre noget ud af Grundtvigs prædikener onsdag den 17. april og 2. søndag efter påske, selv om de tydeligt giver indtryk af, at Grundtvig er ved at komme sig. Men særlig opmærksomhed fortjener prædikenen på 3. søndag efter påske (28. april 1844), hvor Grundtvig prædiker om Jesu ord om den liden stund (Joh 16,16-22), hvor hovedsagen bliver, at vi skal sige til hinanden: "om en liden Stund skal I ikke see os, og atter om en liden Stund, da skal I see os, thi vi gaaer til Faderen!" (Begtrup 1924, 107) og Grundtvig kan sige om sig selv: 
thi jeg gaaer til Faderen, til den Gud-Fader, som er skjult for de Lærde og Kloge, men aabenbaret de Umyndige [Matt. 11,25], til Ham og Hans Huus, til Huset, bygt uden Hænder, evigt i Himlene, hvis Dør for os hedder Syndernes Forladelse, hvis Alterbord er Naade-Stolen i Vorherres Jesu Christi Blod; ja, til Fader-Huset gaaer jeg, til Guds Børns Hjem, hvor de Sidste skal tale med de Første, og Alle sige Eet, og dog drikke Saligheds Fryd af hinandens Læber, i Livets, det evige Livs, den evige Lovsangs, den guddommelige Kiærligheds og Glædes for os usigelige Ord; ja, der gaaer jeg hen, men gaaer kun som de Smaa, der bæres frem at lægges paa Herrens Arme, som velsigner dem og vidner: Himmeriges Rige hører Saadanne til [Markus 10,14b]; ja, saaledes gaaer jeg, baaret af Ham, som bar vore Synder paa sit Legeme paa Træet, drevet af Hans Aand, og svøbt i Hans Retfærdighed, ombæltet med Hans Kiærlighed; og saavist som jeg der skal see alle Disiplerne fra Simon Peter til Morten Luther og derefter, saavist skal I ogsaa der Alle see mit Ansigt igien, og jeg eders, med evig Fryd og Glæde! (ibid., 110).

Den liden stund er kun et øjeblik, i himlen langt mindre end det, og Herrens ord står fastere end himlen og jorden. Derfor lad os være glade!

På den ene side argumenterer Grundtvig med omhu for, hvordan Jesu ord om den liden stund kan tilegnes af de troende. På den anden side tager Grundtvig dem selv i munden i en form, der utvetydigt forudsiger hans død og farvel til menigheden. Og indholdet $i$ "Sov sødt, Barnlille" skimtes tydeligt.

Det kommer markant til udtryk i hans sidste prædiken onsdag den 1. maj 1844, førend han med sin familie rejser på rekreation (prædikenen er gengivet s. 68 ff. i denne udgave af Grundtvig-Studier, og sidehenvisningerne i det følgende henviser hertil ). Han havde selv valgt sin tekst, nemlig Rom 10,5-17, især på grund af ordene i 10,8 "Ordet er dig nær, i din mund og i dit hjerte. Nemlig det troens ord, som vi prædiker".

I det følgende taler Grundtvig - ligesom i den foregående prædiken - helt usædvanligt i jeg-form: De nævnte Paulus-ord betød alt for ham i hans ungdom, hvad angår ordets forkyndelse og salighedens vej. Afgørende fremhævedes forkyndelsen af Guds ord, som skulle tros og bekendes og dermed gjorde de troende retfærdige og visse på saligheden - en erkendelse, som ingen vil nægte nu, men som dengang havde verden imod sig, hvorfor Grundtvig holdt sin berømte prædiken "Hvi er Herrens Ord forsvundet af Hans Hus?" (US II, 5-20), hvormed hans kamp for den gamle kristendom begyndte:

Nu m.V. denne gode Strid har jeg stridt og bevaret Troen, om jeg har fuldendt Løbet [2 Tim 4,7], det veed kun Gud, og det staaer i Hans 
Haand, men jeg skylder Ham og Sandheden og Herrens Menighed, som Han kiøbde med sit Blod, det Vidnesbyrd,..." (s. 69 ),

at det var Ordet og troen, der bar Grundtvig og ikke omvendt, og af Guds nåde var og er Grundtvig, hvad han var og er. Dengang stod det ham ikke klart, hvad det er for et troens og bekendelsens ord, men ud fra de nævnte Paulus-ord kom Grundtvig til "den kirkelige anskuelse", og fandt som grundlag Trosbekendelsen i Luthers lille Katekismus, den fælles trosbekendelse, som ved sin overensstemmelse med det bibelske vidnesbyrd viser, at "den kirkelige anskuelse" ikke er Grundtvigs påfund.

Derfor kan Grundtvig roligt slutte sit vidnesbyrd (jf. 1 Joh 5,10), og det er et udtryk for Guds nåde, at Hans gamle og svage tjenere alligevel er stærke i deres skrøbelighed (S1 71,9; 2 Kor 12,9),

saa det bliver soleklart, vi trængte selv høilig til Gud og hans Ord til at holde os opreiste og stride den gode Strid, da først nødes Verden til at see, hvad der er Menigheden indlysende, at vi bære Klenodiet $\mathrm{i}$ Leerkar, saa den overvættes Kraft, som følger Ordet, er Guds [2 Kor 4,7] og er ingenlunde af os (s. 70 ).

Troen og tilliden i salighedens sag skal flyttes fra os, som kommer og forsvinder, for det er Gud alene, der gør os dygtige i den nye pagts tjeneste $(2$ Kor 3,6$)$. Alle kristne må vide, hvordan det går til, at Ordet bliver levende for os; det sker ved tilegnelsen, fordi Herren siger, at alt, hvad han gjorde - i nadveren, i inkarnationen og i sin opstandelse - er sket for os. Ved denne tro bliver Ordet levende i os. Og til sidst hedder det opsummerende som i et testamente:

Dette er det Klareste, jeg endnu kan sige om disse dybe Ting, og jeg vil slutte med Apostelen Pauli dyrebare Ord: jeg overlader eder, Medchristne, Brødre og Systre i Herren, til Gud, og til Hans Naades Ord, som er mægtigt til at opbygge eder og give eder Arv med alle Hans Hellige [ApG 20,32], thi I skal alle have Fællesskab med os og med Herrens Apostler, ligesom de og vi med dem, har Fællesskab med Faderen og med Hans Søn, Jesus Christus, i den Hellig-Aand; og dette Fællesskab har alle Troende i den Hellige Nadver, saavist som det er et Guds Ord til os alle: tager hen og æder, det er mit Legem! drikker alle heraf, det er den ny Pagts Kalk i mit Blod, som udgydes for eder til Syndernes Forladelse! (s. 71.).

Prædikenen er en enestående afskedstale i Grundtvigs mund, majestætisk og klar i formen og $\mathrm{i}$ indholdet med beskrivelsen af hans egen kristendom og arv til sine tilhængere. Grundtvigs sjælelige nedtrykthed tager ikke ordet ud af hans mund, selv om han synes at tale for sidste gang 
Den 3. maj 1844 sejlede Grundtvig sammen med sin familie på en rekreationsrejse. ${ }^{5}$ I et brev forinden (2. maj 1844) skriver han til Gunni Busck:

Da Hovedet ei endnu staaer ganske rigtig paa mig, har jeg besluttet, vil Gud, at reise lidt rundt i Sælland med hele Familien, og, skiøndt det, efter Omstændighederne, er lidt nærgaaende, kan jeg jo dog ikke reise Landet om, uden at komme til Stifts-Bjergby (s. 77).

og han anmelder sin ankomst til 17. maj 1844 . $^{6}$

Grundtvigs brev krydser et brev af samme dato fra Gunni Busck (NKS 2710,2 $2^{\circ}$ jf. s. 77 f.). Brevet røber, at der må have været en kontakt imellem de to nære venner få dage forinden; Grundtvig har inden sine rejseplaner - bedt Busck komme og tage ham til alters. Busck må også have hørt om Grundtvigs prædiken 3. søndag efter påske; han indleder sit brev med et citat fra Prædikerens Bog $(11,9)$ : “'Gud velsigne Dig i din Barndom!['] Det var mit Hjertes Bøn for Dig min kjære Ven! og det er saa endnu og vil med Vor Herres Hjelp blive indtil Enden" - ord, der bliver helt uforståelige uden den nævnte prædiken som baggrund - især Grundtvigs ord om at blive båret som et barn til Guds favn. Og brevet slutter:

Ja ikke en Eneste Sjæl, som er af Sandhed, kan vises bort fra den ligesaa milde som mægtige Faderhaand; men hvad der indtil Enden beviser sit Had mod Sandhed, det viser at det maa skilles fra Sandheden saa der bliver det svælgende Dyb imellem. Dog saalænge vi kunne haabe for nogen Sjel o Gud lad Du os haabe, at den ved din Naade kan blive ædru af Djævelens Snare.

Måske hentydes til, at Grundtvig i sin depression i hvert fald har trodset Djævelen (jf. strofen ovenfor, s. 39). Overhovedet virker Buscks brev om Grundtvigs tilstand som et forspil til "Sov sødt, Barnlille".

På sin rejse drog Grundtvig i første omgang til sin ven på Møen, sognepræst P. L. B. Ingerslev, i Magleby Præstegård. ${ }^{7}$ Fra Magleby rejste Grundtvig til Peter Rørdam i Mern. Om opholdet i Mern Præstegård og om tiden efter depressionen skrev Grundtvig langt senere (6. august 1844) som svar på et ikke bevaret brev fra Rørdam (Rørdam 1892, II, 10-13), hvori det blandt andet hedder:

Jeg har, Gud være lovet! nu faaet hele min Aandskraft tilbage, ja vel endog faaet den forøget, og ved Vandringen gjennem 'Dødens Skyggedale' [Sl 23,4] ved Lyset, som aldrig forlader den troende Christen, om han end drømmer sig forladt, vundet et nyt, langt klarere Lys over Livet, baade her og hisset, skiøndt det nok kan være, at baade de og mine fleste Venner, ved at see mig i det daglige Liv, vilde ryste paa Hovedet og ei vide, hvad De skulde tænke. Dog, dertil er jeg gammelt vant, saa kun naar jeg selv bringes i Vildrede og veed ei, 
hvad jeg skal tænke enten om Vorherre eller Mennesket og mig selv, kun da kniber det.

Grundtvig fortæller videre, at hans udsigter $\mathrm{i}$ hele tre måneder har været bælgmørke, så lang tid har hans depression varet, men

saa oprinder Lyset morgenrødt over Skoven og Havet og selv over Bjergene! Ja, jeg er, giennem min sidste Trængsel, blevet mere Digter igien, end jeg har været i mange Aar, saa De vil finde meget Nyt at synge hos mig; det er min Svanesang, som begyndte med Vugge-Visen for Guds-Barnet i Jordens Moder-Skiød, og da selv de smaa Forskjelligheder i den er Hovedbegivenheder i mit aandelige Liv, vil jeg opskrive den heel, som den nu daglig lyder i min Ensomhed hos Vorherre.

Derefter gengiver Grundtvig i sit brev de 6 vers af "Sov sødt, Barnlille", i den form, han selv er nået til på dette tidspunkt, dvs. den venstre spalte omfattende strofe 1 og 3-4 og den midterste spalte omfattende stroferne 2, 5 og 7 (nedenfor skal salmens tilblivelse gennemgås) ${ }^{8}$ :

1

Sov sødt, Barnlille!

Lig stille, lig stille,

Saa sødelig sov,

Som Fuglen i Skov,

Som Blomsterne blunde i Enge!

I Faderens Skiød,

Med Kiærligheds Glød,

Selvanden du hviler i Senge.

2

Med Fingrene sande

Slaae Kors for din Pande!

Med Gudsbarnets Røst

Slaae Kors for dit Bryst!

Saa kan ingen Djævel dig giæste;

Saa skal om din Daab,

Med Saligheds-Haab,

Sig Mindet i Barmen ${ }^{9}$ rodfæeste!

3

Læg Hænderne sammen!

Lad dem sige Amen

Til Mesterens Bøn,

Som stiger i Løn,

Og høres ${ }^{10}$ hvor Englene kvæde!

Det lille Guds-Ord,

Som stiger fra Jord,

Omfavne Guds Engle med Glæde. 
4

De raabe, de sjunge:

$\mathrm{Paa}^{11}$ Madike-Tunge

Et Ord af Guds Søn

Er blevet til Bøn,

Og stiger paa Solstraale-Vinger!

Gud-Fader i Løn!

Sig Ja til den Bøn!

O hor dog, hvor himmelsk den klinger!

\title{
5
}

Da alle de Kiøbte

I Jesu Navn døbte,

Som Striden har stridt,

Som Døden har lidt,

Gik ind til den evige Hvile,

Istemme saa lydt,

Halleluja nyt

At Englene tie og smile!

\author{
6 \\ Da drypper som Duggen \\ Der Manna paa Vuggen \\ Til Barnet paa Jord \\ Fra Englenes Bord, \\ Du finder med Smil det i morgen, \\ Og klarøiet brat \\ Du siger godnat \\ Til Tvivlen og Frygten og Sorgen!
}

\author{
7 \\ Sov sødt, Barnlille! \\ Lig rolig og stille \\ Og nyn paa det Navn, \\ Med Fylden i Favn, \\ Al Jorden til Salighed givet! \\ Nyn: Jesus er min, \\ Saa faur og saa fiin, \\ Min Jesus er Lyset og Livet!
}

Grundtvig sluttede sit brev i en bemærkelsesværdig højtidelig stil med et næsten profetisk indhold, som om han fra en anden verden forkyndte et testamente:

$\mathrm{Nu}$, min Ven! jeg har ikke mange Stunder; thi Natten kommer, da Ingen kan arbeide [Joh 9,4], og jeg har endnu meget at giøre, før jeg lægger mig til Hvile i det velsignede Navn, der ogsaa hos mig og paa mig har beviist sin guddommelige Magt og sin menneskelige men dog himmelske Liflighed, og vil herefter bevise begge Dele endnu langt klarere, skiøndt det Altsammen kun bliver dunkelt mod den Klarhed, 
det havde hos Faderen, før Verdens Grundvold blev lagt [Matt. 13,35], og kun matte Glimt af den Herlighed, der skal aabenbares paa os, naar Han kommer at blive herlig i sine Helgene og vidunderlig i alle sine Troende! [2 Tess 1,10].

I et tidligere brev af 14. juli 1844 nævner Rørdam, at han mangler, hvad han kalder "Det 4de Vers af Deres Vuggevise" (Rørdam 1892, I, 311), uden at man sikkert kan vide, hvilken strofe han kan have tænkt på. Peter Rørdam skriver: "P. Boisen, der sendte mig det øvrige, glemte det". Måske havde P. Boisen sendt hele salmen på 6 strofer, hvor 4. strofe af en eller anden grund manglede.

En gammel tradition vil vide, at stroferne $i$ den venstre spalte (nummereringen af stroferne er den samme som i den nuværende salmebog) er blevet til under Grundtvigs ophold i Mern Præstegård, fordi de første strofer ( 1 og 3-4) er tydeligt mærket af Grundtvigs angst for døden med udtrykket "Paa Madike-Tunge", og fordi en række digte sandsynligvis hidrører fra opholdet i Mern, hvor man foretog en udflugt til Udby, hvor Grundtvigs far og søster er begravet, begivenheder, der kan have inspireret Grundtvig til fire usædvanlige "gravdigte" refererende til moderens, faderens og søsterens grave samt til sin egen grav ( $V U$ VIII, 230-31). Især det sidste digt påkalder sig interesse i denne sammenhæng:

VED MIN EGEN GRAV.

En Træl af Kiød og Blod,

Og tiggerarm paa Mod,

En Kæmpe dog i Færd,

Sig hviler trøstig her

I Kraft af Barnedaab,

Med Herlighedens Haab.

Faa levede saa frit,

Og virkede saa bundet,

$\mathrm{Og}$ sjelden for saa vidt

Blev Døden overvundet,

Fordi man længe ei

Slog ind den gamle Vei:

Paa Herrens egne Ord

Ved Kirkens Bad og Bord,

I Jesu Navn udvalgt

At troe og vove Alt,

Og i hans Kirkes Skiød

At trodse Synd og Død,

Og i hans Vennelag

At vente paa hans Dag

Med Evighedens Krands

Med Herlighedens Glands. 
Denne "gravskrift" ligger tæt op ad "Sov sødt, Barnlille" og baggrunden for digtet overhovedet, når der tales om at være "træl" og "tiggerarm", og når der som trøst nævnes barnedåben med herlighedens håb, der kan tolkes som et kodeord for Fadervor (Se Thodberg $1989,68 \mathrm{ff}$ især 78).

Fra Mern rejste Grundtvig til Ferdinand Fenger i Lynge Præstegård ved Sorø, og hans vært dér lærte de første tre vers at kende. Det samme gjaldt P. A. Fenger i Slotsbjergby ved Slagelse, hvortil Grundtvig ankom til Kristi Himmelfartsdag (den 16. maj 1844), inden han besøgte Gunni Busck i Stiftsbjergby Præstegård.

Et andet vidnesbyrd om Grundtvigs krise er det digt til datteren Meta, hvori han mindes sin nedstemthed og datterens trøst. ${ }^{12}$ Heri hedder det blandt andet:

Du Lille, du Kiære! da Sindet var sygt,

Mit Hoved var ørt, men mit Hjerte var mygt,

Da Vanvid mig trued,

Og Vennerne grued,

Da ømt mig betragted med Smil giennem Taaren

Min Datter eenbaaren,

Som jeg dig betragter i Sommerdags-Kveld

Og hvisker Farvel!

Hermed nærmer jeg mig også Jørgen Ertners vigtige afhandling: Et ord af Guds Søn. Salmen "Sov sødt, barnlille" og dens tilblivelse (Ertner 1997, 185-211), som jeg står i stor gæld til - tilmed med stor glæde, for jeg ser, at han og jeg i mange enkeltheder er enige om tolkningen af salmen, men først og fremmest fordi han på fortjenstfuld måde har løst gåden om tilblivelsen af de forskellige dele af "Sov sødt, Barnlille", således som det allerede i tilslutning til Ertner her er blevet skitseret. Det skyldes ganske særligt hans fund af et ellers savnet brev af 28. maj $1844^{13}$ fra Grundtvig til Ferdinand Fenger, som besvarede brevet 3. juni 1844 ( $B G$ II, 396). Det nyfundne brev er af største interesse. $^{14}$

I sin gennemgang af salmen lægger Jørgen Ertner vægten på salmens tidligste form (spalten til venstre med stroferne 1, 3 og 4) og understreger med rette Fadervors centrale betydning. Det resultat vil jeg gerne supplere ved at understrege de forudgående prædikeners betydning for salmen, og at mange af motiverne i salmen hidrører fra Grundtvigs almindelige teologiske og poetiske begrebsverden.

I den sammenhæng er P. A. Fengers brev til Grundtvig af 28. maj 1844 også af betydning ( $B G$ II, 393-395). Fenger skriver om, hvor længe han har ønsket at få besøg af Grundtvig, og hvor skuffet han i første omgang blev. Han vurderede besøget som en slags "bispevisi- 
tats”, men desværre faldt Grundtvig i søvn under prædikenen! (Kristi Himmelfartsdag - 16. maj 1844) og han havde heller ikke kræfter til at være med til husandagten om aftenen:

Skjønt saaledes Deres Besøg i denne Henseende ikke blev, hvad jeg havde tænkt, saa blev det i andre Henseender mere, end jeg havde ventet. Især Deres Meddelelse af Præken: 'om en liden Stund, og thi jeg gaar til Faderen' og Deres Vuggevise vederkvægede min Aand, og det er længe siden jeg hørte et Ord, der saaledes opmuntrede og opbyggede mig som dette.

Fenger bekræfter således den nære forbindelse mellem på den ene side Grundtvigs prædiken om den liden stund på 3. søndag efter påske og på den anden side salmen. Dengang som nu har Grundtvigs salme om gudsforladtheden gjort indtryk! "Jeg haaber længe endnu at skulle have Gavn og Glæde deraf".

Mange andre kilder vidner om, at "vuggevisen" snart var på alles læber i de grundtvigske kredse. Men Fengers brev røber også, at Grundtvig på sin rekreationsrejse ikke blot medbragte "Vuggevisen" i den korte version (Jf. $B G$ II, 397, 398), men han medbringer også mundtligt eller skriftligt - sin prædiken fra 3. søndag efter påske. I det følgende skal salmen ud fra oversigten (her s. 48 f.) gennemgås i dette perspektiv:

\section{Strofe 1:}

I prædikenen på 3. søndag efter påske lægger Grundtvig sine tilhørere på sinde at følge det husråd, som også lod sorgen afløses af glæde for Jesu disciple og agte på barnetroen. Og når han begynder med

Sov sødt, Barnlille!

Lig stille, lig stille,

Saa sødelig sov,

Som Fuglen i Skov,

Som Blomsterne blunde i Enge!

siger han i grunden ikke noget nyt. Allerede i 1824 nævner han, at det er den barnlige tro, som den voksne skal generhverve i "Velkommen igen, Guds engle små", når den voksne ser sine børn ligge sovende $\mathrm{i}$ sengene (DDS03 99,4):

Med venlige øjne himmelblå,

I vugger og i senge,

Vi puslinger har i hver en vrå,

Som blomster gro i enge!

$\mathrm{O}$, synger for dem, som lærker slå,

Som hørt de har ei længe! 
I julesalmen fra 1824 er det julesorgen, der dermed skal slukkes (DDS03 99,8). For ligesom barnemoderens vé og smerte afløses af glæde, når barnet først er født, således genfødes ved Jesu død og opstandelse et nyt menneske af troen (Begtrup 1924, 109) - ligesom et barn med den samme ro og ubekymrethed som fugle og blomster (Matt. 6,25-29), dvs. med det konkrete barndomsminde, som ethvert menneske har en erindring om, ${ }^{15}$ for "barnet" ligger sammen med Jesus i Faderens skød (jf. Joh 1,18b). Grundtvig indleder sin salme med trøsten, som han har sunget om så mange gange før, ja, det er, som om trøstens og husrådets løfte allerede er indfriet. For til "barnet" siges:

Med Kiærligheds Glød,

Selvanden du hviler i Senge.

der for nogle (og måske også senere hen for Grundtvig selv) har lydt for intimt. Men fra begyndelsen var det en salme, Grundtvig skrev for sig selv, da han afkræftet lå i sin seng. I den følgende tid ændres salmen. Den bliver så at sige "afpersonaliseret". Allerede i 1845 er de tre sidste linier ændret til

Gud Fader har sagt:

Staaer Engle paa Vagt [jf. Matt 18,10],

Hvor mine de Smaa er i Senge! ${ }^{16}$

Strofe 3:

De tre strofer i den venstre spalte har altså været en trøstende salme for Grundtvig i den allerførste periode i hans dybe depression (Ertner 1997, 186-187). Bønnen Fadervor står i centrum: den, der beder bønnen, lægger alene ved sin gestus: de foldede hænder et amen til Fadervor, den bøn, som Jesus selv siger, når bønnen lyder på vore læber, eller når vi selv ikke kan få bønnen sagt. ${ }^{17}$ Men netop fordi det er Sønnen, der beder, hører Faderen bønnen til englenes glæde. Det er i den sammenhæng mærkeligt, at Grundtvig her siger "Mesteren" og ikke Frelseren. Det rettes op i versionen fra omkring 1850 (GSV IV 193,4 jf. Malling IV, 410):

Læg Hænderne sammen!

Da lægger sig Amen

Til Frelserens Bøn,

Som stiger i Løn

Og lyder, hvor Englene kvæde,

I Himmerigs Kor

Det lille Gudsord

Omfavne Guds Engle med Glæde. 
Strofe 4:

Tankegangen fortsætter naturligt i det sidste vers i den venstre spalte med englene, der står for Guds trone og råber og lovpriser Gud Fader i himlen, fordi "et Ord af Guds Søn", Fadervor, som englene kender som Jesu bøn, pludselig lyder fra et jordisk menneske i den dybeste gudsforladthed. Det kommenteres af Johs. Ferdinand Fenger i hans ovenfor nævnte brev til Grundtvig af 3. juni 1844. Det gælder den anden linie af de fire første linier:

De raabe, de sjunge:

På Madike-Tunge

Et Ord af Guds Søn

Er blevet til Bøn,

Fenger finder det rimeligt, at englene "kalder os Stakler 'Maddiker', men en anden Sag er det med 'Maddike-Tunge'. Da Maddiker ingen Tunge har og den hele Ormeslægt er maalløs, saa er Billedet, om jeg skjønner ret, forfeilet" ( $B G$ II, 396). Grundtvig kommenterer denne kritik i et brev til broderen, P. A. Fenger, af 8. juni 1844:

Broder Ferdinand har jeg sendt tre Vers til at giøre Vuggevisen fuldstændigere, og havde i den Anledning et venligt Brev fra ham, hvori han vel, i mine Øine meget ufornuftig, giør naturhistoriske Indvendinger mod det Poetiske Udtryk 'Madike-Tunge', men Sligt er saa sædvanligt, at jeg ei skulde anmærket det, naar Sligt ikke var en af de store Hindringer for en god Psalmebog (ibid., 397).

I det nyfundne brev af 28. maj 1844 fra Grundtvig til Ferdinand Fenger forsvarer Grundtvig det kritiserede udtryk og tilføjer, at det "passer bedst til os daarlige Efterlignere af Ham, der sagde 'jeg er en Orm og ikke en Mand' [Kingo], og er desuden en gammel Medicin for min gamle Adam" (ibid., 396). At det for Grundtvig er "en gammel Medicin" betyder næppe andet, end at han har haft nytte og gavn af klare ord om menneskets forkrænkelighed. ${ }^{18}$ I modsætning til "orm" understreges forkrænkeligheden langt stærkere af ordet "maddike", navnet på det væsen, der i graven opæder liget. Det svarer til den gudsforladthed og dødsangst, der så markant gør sig gældende i de to sidste prædikener, Grundtvig holder på 3. søndag efter påske og 1. maj 1844 , hvor han bogstaveligt som prædikant taler som et menneske, der står med det ene ben i graven og officielt tager afsked både med sin menighed og med selve livet. Han taler andre steder lige ud om gravens mørke og kulde. Dét er ikke poesi, men hård virkelighed. Derfor er "maddike-tunge" et enestående vidnesbyrd om Grundtvigs teologiske virkelighedsforståelse: hans modsætning er modsætningen mellem liv og død, og derfor burde han ikke have bøjet sig for Ferdinand Fengers pedanteri. "Sov sødt, Barnlille" var en salme for 
ham selv ligesom "At sige Verden ret Farvel". I det sidste tilfælde nægtede han som bekendt at ændre udtrykket "Døden, med sin IistapHaand", men måtte alligevel lide den tort, at hans gode ven, B. S. Ingemann, i 1855 ændrede det til

Før Døden med en iskold Haand

Giør Skjel imellem Støv og Aand, ${ }^{19}$

Først omkring 1850 bøjede Grundtvig sig for kritikken og ændrede "Paa Madike-Tunge" til det "grundtvigske", men i denne sammenhæng mattere "Paa Jordklimpens Tunge", mattere, fordi den hårde modsætning mellem død og liv derved svækkes. Andre småændringer forbedrer faktisk strofen, da de - med Grundtvigs accept - kom ind de sidste i $1872^{20}$ :

Guds-Englene sjunge:

Paa Jordklimpens Tunge

Et Ord af Guds Søn

Er bleven til Bøn,

Svang hid sig paa Aandedræts-Vinger;

Gud Fader i Løn

Sig Ja til den Bøn,

Fra Lavland livsalig den klinger!

\section{Strofe 2:}

Med henvisning til den just anførte reviderede strofe 4 er vi allerede i gang med salmens videre udvikling, nemlig de tre vers i den midterste spalte, som Grundtvig efter alt at dømme skrev under sit ophold hos Gunni Busck og meddelte Ferdinand Fenger i brevet af 28. maj 1844.

Ganske vist kan de tre strofer (1, 3-4) opfattes som en kort salme om Fadervor, vel at mærke som en rigtig bøn - ikke en bøn, der kan loeses, men en bøn, der virkelig bedes, og det er kun for alvor tilfældet med Fadervor bedt i Jesu navn, og for det andet hænger det for Grundtvig tydeligt sammen med Fadervor ved dåben. Han indrømmer selv, at det var en erkendelse, han først efterhånden kom frem til; han siger i 1855: "Det varede længe med mig selv, inden jeg ret kom efter, hvor deilig Herren ved Daaben selv laerer os at bede, ligesom han selv loerer os at tro, og hvormed han skiænker os Børne-Retten..." (US IX, 384).

Salmen "Sov sødt, Barnlille" har efter alt at dømme spillet en afgørende rolle i udviklingen af Fadervors betydning for Grundtvig. Eller sagt på en anden måde: først efterhånden fik Fadervor status som "et ord af Herrens egen mund".

Et tilløb møder man i Sangværkets 1. bind i det store digt (26 strofer) om Fadervor, nr. 92. Her skelnes der mellem denne bøn, når 
den læses, og når den bedes. Ikke engang Fadervor i nadverritualet før Indstiftelsesordene regner man for noget (92,1-3). Herefter hedder det $(92,4)$ :

Som det gaaer med Herrens Bøn,

Saa med Navnet paa Guds Søn,

Rod til Bønnens Dyder:

$\mathrm{Faa}^{21}$ kun lyder saa i Favn

$\mathrm{Nu}$ vor Herres Jesu Navn,

At det Hjertet fryder!

Hvordan skal man forstå udtrykket "i Favn”? Her røber Grundtvig på en meget dunkel måde, at han forbinder forståelsen af Fadervor med denne bøns plads i dåbsritualets struktur: Efter læsningen af Markus 10,13-17, der slutter med ordene: "Han tog dem i Favn, og lagde Hænderne paa dem, og velsignede dem", siger præsten: "Saa ville vi og til samme Velsignelse forhjelpe dette lille Barn med vor andægtige Bøn til Gud: Fader vor,...". 22

Alt tyder på, at den "mageløse opdagelse" i 1825, hvor - som det hedder - Grundtvig "fandt" den apostolske trosbekendelse, snarere burde forstås som Grundtvigs opdagelse af, at forsagelsen og trosbekendelsen $\mathrm{i}$ den spørgende form ved dåben og Indstiftelsesordene ved nadveren i den indbydende form, blev "Guds ord til os", samt at hele dåbsritualet fra først til sidst fik den samme status, og ganske særligt blev også Fadervor "Guds ord til os" og sagt af os $i$ Jesu navn den bøn, Han beder for os, fordi vi én gang for alle ved dåben er blevet lagt $\mathrm{i}$ Hans, $\mathrm{i}$ Guds favn som Jesu brødre og søstre. ${ }^{23}$

Det er netop denne tryghed hos Gud, der på en særlig stærk måde kommer til udtryk i Grundtvigs prædiken på 3. søndag efter påske 1844 , når Grundtvig tilegner sig Jesu ord om "den liden stund" og siger:

ja, til Fader-Huset gaaer jeg, til Guds Børns Hjem, (...) ja, der gaaer jeg hen, men gaaer kun som de Smaa, der bæres frem at lægges paa Herrens Arme, som velsigner dem og vidner: Himmeriges Rige hører Saadanne til [Markus 10,14b]; ja, saaledes gaaer jeg, baaret af Ham, som bar vore Synder paa sit Legeme paa Træet, drevet af Hans Aand, og svøbt i Hans Retfærdighed, ombæltet med Hans Kiærlighed," (Begtrup 1924, 110).

Det er ordene om at "bæres frem at lægges paa Hans Arme" og de andre ord og vendinger fra dåbsritualet, der lyder et ekko af, når det $\mathrm{i}$ den første strofe af den oprindelige version af "Sov sødt, Barnlille" siges til "barnet":

I Faderens Skiød,

Med Kiærligheds Glød,

Selvanden du hviler i Senge. 
Måske afspejler ordvalget Grundtvigs faktiske situation: Efter sammenbruddet ligger han afmægtig i sin seng, men Jesus, lyset og livet, er hos ham.

Grundtvigs sammenbrud og "Sov sødt, Barnlille" sætter et afgørende skel i hans liv. Det fremgår af, at "Fadervor" og "Guds favn" fra nu af kædes sammen i salmerne. ${ }^{24} \mathrm{Og}$ salmen er på nippet til at blive et fast element i Grundtvigs aftenbøn. Morgen- og aftenbønnen i hans hjem gjorde et dybt indtryk på dem, der opholdt sig i huset. ${ }^{25}$

Modellen er Luthers anvisninger i Den lille Katekismus om, hvordan en husfader skal holde morgen- og her især aftenandagt. Det hedder med tydelig henvisning til dåbsritualet $\mathrm{i}$ Grundtvigs private opskrift til andagten i sit hjem:

Det hellige Korsets Tegn baade for vort Aasyn og for vort Bryst, draget ved den hellige Daab i Jesus Kristus-Navnet til fuld og klar Skilsmisse mellem os og den Onde og til et evigt Vidnesbyrd om, at vi høre dig til, korsfoestede, men igjen opstandne Herre Jesus Kristus!.... ${ }^{26}$

Derefter følger bønnen til Helligånden og udførlig citation af Forsagelsen og Trosbekendelsen og omtale af nadveren og til sidst et mere eller mindre fast salmevers. Men efter 1844 stod én salme i centrum: "Om Aftenen sang man: 'Sov sødt, Barnlille', jeg tror som den findes lidt omarbejdet og forkortet i 'Festpsalmerne'" (Brun 1882, 734-736). Efter alt at dømme drejer det sig om stroferne 1-2 plus sidste strofe.

"Vuggevisen" har med andre ord tidligt fået en særlig stilling for Grundtvig som en trøst for og til ham selv. Det er derfor heller ikke mærkeligt, at han nødigt opgiver "Madike-Tunge", og at han i den følgende tid ændrer enkelte ord og vendinger i salmen for klarhedens skyld. Uden at gå i enkeltheder må man vist erkende, at Grundtvigs depression sprogligt afspejles i salmens forste version: stroferne synes af og til at være ubehjælpsomme, og Grundtvig synes af og til at ligge under for rimnød. Stroferne trænger rent ud sagt til at blive strammet op!

Det mest oplagte eksempel på det er ændringerne af strofe 2 (2. spalte) ved en sammenligning mellem 1844-versionen og den sidste version i 8. udgave af Festsalmer: 
1844:

Med Fingrene sande

Slaae Kors for din Pande!

Med Gudsbarnets Røst

Slaae Kors for dit Bryst!

Saa kan ingen Djævel dig giæste;

Saa skal om din Daab,

Med Saligheds-Haab,

Sig Mindet i Barmen rodfæste!
Festsalmer (8. udg.):

Guds-Fingrene grande

Slog Kors for din Pande,

Guds Eenbaarnes Røst

Slog Kors for dit Bryst,

Thi skal ingen Djævel dig skade;

$\mathrm{Nu}$ kan i din Daab

Med Saligheds-Haab

Din Sjæl og dit Hjerte sig bade!

Hvad 1844-versionen angår, kritiserer Ferdinand Fenger foruden ordet "Madike-Tunge" også denne strofe: "Det Samme gælder om 'Fingrene sande' i V 2, skjønt paa en anden Maade" ( $B G$ II, 396). Fenger konkretiserer altså ikke sin indvending. Når Grundtvig her taler om "de sande fingre", er det naturligvis Guds fingre (Thodberg 1989, 1829); det er ikke umiddelbart forståeligt, og det virker unægteligt kunstigt, at den bedende skal slå kors med den Almægtiges hånd. Det bliver naturligvis til dels forklaret i linie 3-5: det er med Jesu røst vi skal slå kors. Eller sagt helt tydeligt: fra nu af hører ordene ved korstegnelsen ved dåben til "Guds ord til os", der forjager Djævelen. Og i linie 6-7 hedder det, at med saligheds håb skal mindet om dåben slå rod i hjertet. Strofen i den første version står kort fortalt svagt; den er vanskelig at forstå, og selv om det hedder, at mindet om dåben skal slå rod i hjertet, forbliver dåben en fortidig handling, der skal gøres levende som et minde.

Man kan forestille sig, at det er betænkeligheder af denne art, der inspirerede Grundtvig til at stramme strofen i versionen til højre. Det er den almægtige Guds fingre alene, der slår kors, selv om det sker med en menneskelig hånd; det bliver tydeligt, at det er korstegnelsen for pande og bryst - for hjernen og for hjertet - erkendelsen og livet, det drejer sig om, så ingen Djævel skal skade det barn, der hører Gud til. Den stærkeste ændring kommer i de tre sidste linier, der taler om, hvad der $n u$ sker: Nu kan du i kraft af din dåb med saligheds håb, dvs. med Fadervor, ${ }^{27}$ bade din sjæl og dit hjerte og åndeligt gentage dåbens tre overøsninger med vand. Mens man i den første version af strofen skulle trøstes af mindet om dåben, understreger den reviderede strofe, at Fadervor reaktualiserer dåben, hvert øjeblik bønnen bedes i Jesu navn. Og påstanden om, at det er Fadervor, der er salmens hovedsag, bekræftes til fulde af den følgende strofe 3 (i den reviderede form (se ovenfor, her s. 48)): 
Læg Hænderne sammen!

Da lægger sig Amen

Til Frelserens Bøn,

Som stiger i Løn

Og lyder, hvor Englene kvæde,

I Himmerigs Kor

Det lille Gudsord

Omfavne Guds Engle med Glæde.

Strofe 4 knytter sig naturligt til slutningen af strofe 3 (se s. 49 og 55):

Guds-Englene ${ }^{28}$ sjunge:

Paa Jordklimpens Tunge

Et Ord af Guds Søn

Er bleven til Bøn,

Svang hid sig paa Aandedræts-Vinger,

Gud Fader i Løn

Sig Ja til den Bøn,

Fra Lavland livsalig den klinger!

Hvad strofe 5 angår, tales der i prædikenen på 3. søndag efter påske om den sidste strid, og onsdag den 1. maj 1844 hedder det i den sidste prædiken før Grundtvigs sammenbrud om hans udholdenhed i troen på Gud:

Nu mine Venner denne gode Strid har jeg stridt og bevaret Troen, om jeg har fuldendt Løbet [2 Tim 4,7], det veed kun Gud, og det staaer i Hans Haand, men jeg skylder Ham og Sandheden og Herrens Menighed, som Han kiøbde med sit Blod [jf. 1 Kor 6,20; 7,23], det Vidnesbyrd, at det var ikke mig, som gav Ordet, men Ordet, som gav mig Kraft til at stride og vinde, og at det var meget mere Troen, som bevarede mig, end mig, som bevarede Troen,... (s. 69 ).

Med forsæt citerer Grundtvig Paulus' afskedsord til Timoteus. Det er Grundtvigs arv, da han nu venter at dø:

$\mathrm{Da}^{29}$ alle de Kiøbte,

I Jesu Navn døbte,

Som Striden har stridt,

Som Døden har lidt,

Gik ind til den evige Hvile,

Istemme saa lydt,

Halleluja nyt

At Englene tie ${ }^{30}$ og smile!

Strofe 6 (i den højre spalte) kendes først fra 1850, dvs. 6 år efter Grundtvigs sammenbrud: 
Da drypper som Duggen

Der Manna paa Vuggen

Til Barnet paa Jord

Fra Englenes Bord,

Du finder med Smil det imorgen,

Og klarøiet brat

Du siger godnat

Til Tvivlen og Frygten og Sorgen!

Til gengæld kan man spørge sig selv, om denne strofe virkelig først er nedfældet så mange år efter og hypotetisk forestille sig, at Grundtvig, der var meget tilbageholdende med offentliggørelsen af Vuggevisen, måske har tilbageholdt denne strofe, der så tydeligt taler om krisen ved at nævne netop tvivl, frygt og sorg. Ihvertfald er den tæt forbundet med prædikenens indhold (3. s. e. påske 1844), når der tales om den himmelske sorg, der ramte disciplene (og os), da Herren døde og forsvandt. Den sorg

som jo dybere den gaaer, bliver deslettere at bære, og desmere frugtbar om en liden Stund paa himmelsk, utabelig Glæde; ja, da skal Sorgen hos os alle være som Kvindens, der føder, og glemmer snart Sorgen over den Glæde, at et Menneske er født til Verden [Joh 16,21]; thi det ny Menneske, som kom herned med Herren Jesus Christus og gienfødtes efter Hans Opstandelse i Hans Disiplers Hjerte, med og til den evige Glæde, dette ny Menneske gienfødes da ogsaa i os af BarneTroen, (...) See, med denne Trøst, de Christnes Trøst, kan ingen Troende være bange for Prøven, hvordan den saa end falder ud idag, thi skulde det end give Sorg og Graad til Aften og Nat, saa kommer dog Morgenen med Frydesang, (...) [Sl 126,5-6] (Begtrup 1924, 109 f.).

Ved at gentage de to første linier af strofe 1 sammenfatter strofe 7 hele salmens indhold ved en enestående smuk poetisk udgave af ApG 4,12: "thi ikke er heller et andet navn under himmelen, som er givet blandt mennesker, ved hvilket det bør os at blive saliggiort":

Sov sødt, Barnlille!

Lig rolig og stille,

Og nyn paa det Navn

Med Fylden i Favn,

Al Jorden til Salighed givet!

Nyn: Jesus er min,

Saa faur og saa fiin,

Min Jesus er Lyset og Livet!

Ingen synes at have givet det at nynne så stærk en mening som Grundtvig. 
Vægten i denne sammenhæng er lagt på at beskrive, hvordan "Sov sødt, Barnlille" udvikler sig til den salme, som vi kender i dag. Jeg ser derfor bort fra en række enkeltheder, for eksempel hvordan Grundtvig på et tidspunkt forsøger at udvide salmen med et ekstra vers.

Her skal kun omtales et lille "efterspil". Ved det grundtvigske vennemøde i 1868, hvor Grundtvig selv var til stede, fortæller Gunni Busck ifølge referatet følgende:

Jeg mindes - det er flere og tyve Aar siden - at da han [Grundtvig] var $i$ en af de Anfægtelser, som aldrig nogen saa højt begavet Aand kan undgaa - thi det er umuligt, at der kunde bevares et ydmygt Sind i et Menneske som har saadanne Gaver, naar Vorherre ikke engang imellem tog paa dem og viste dem, at de dog var skrøbelige og at han alene var den mægtige og stærke - da han var i en saadan Anfægtelse, kom han til mig i min Præstegaard, hvor jeg før var. Han havde Bekymring, ja inderlig Bekymring, men Gud trøstede ham. Da vi en Dag sad oppe i et Lysthus, som jeg havde bygget paa en Mark, hvorfra der var en vid og dejlig Udsigt til alle Sider, sagde han til mig: har Du Pen og Blæk, hvortil jeg svarede ja. Saa sagde han til mig: sæt Dig og skriv hvad jeg siger til Dig, og derpaa sagde han følgende.

Ifølge Busck - eller mødets referent - anførtes de første to vers af "Sov sødt, Barnlille", vel at mærke i den form, som salmen i mellemtiden - i 1844-45 - fik, som det her er søgt beskrevet (Køster $1868,14 \mathrm{ff}$.$) .$

Der er hverken af den eller andre grunde anledning til at fæste lid til referatet, men nok til den påstand, at Grundtvig skrev stroferne 2, 5 og 7 i Stiftsbjergby Præstegård, førend han derefter rejste tilbage til København. ${ }^{31}$ At det er sket under særlige omstændigheder, der har gjort indtryk på Gunni Busck, fremgår af Buscks brev til Grundtvig af 23. maj 1844, lige efter at Grundtvig var rejst; dér hedder det til sidst: "Mange mange venlige Hilsener fra os til Jer Allesammen og til din Kone særskilt fra mig Ønsket ja Bønnen for hende til Gud, at dette foelleds Fader Vor maa vare et evigt Fadervor!" (Fasc. 460, jf. s. 79). Senere - i et brev af 1. juli 1844 (Fasc. 460, jf. s. 83) - vender Busck i slutningen tilbage til det samme emne: "Med hjertelig Hilsen og Bøn til Gud om det evige Fadervor mellem de aldrende Ægtefolk!” .

Grundtvig talte så vidt vides aldrig om "det evige Fadervor", men man kan forestille sig, at Grundtvig har nævnt de resterende vers af "Sov sødt, Barnlille" i forbindelse med for eksempel en aftenandagt, der sluttede med et fælles sagt Fadervor, der har gjort særligt indtryk på Lise Grundtvig. 


\section{Forkortelser}

$B G \mathrm{I}-\mathrm{II}=$ Georg Christensen og Stener Grundtvig (udg.) (1926), Breve fra og til N. F. S. Grundtvig, bind 1-2, København.

Danskeren I-IV $=$ N. F. S. Grundtvig (1848-51), Danskeren, et Ugeblad, bind 1-4, København.

DDS03 = Den Danske Salmebog (2003), København.

Fasc. $=$ Fascikel, dvs. håndskriftskapsel i N. F. S. Grundtvigs arkiv på Det Kongelige Bibliotek.

GSV I-VI = Balslev, Th. et al. (1944-64), Grundtvigs Sang-Vark.

Samlet Udgave, bind 1-6, København.

$\mathrm{KB}=$ Det Kongelige Bibliotek.

NKS = Ny Kgl. Samling, Det Kongelige Bibliotek.

PS I-IX = Svend Grundtvig et al. (udg.) (1880-1930), N. F. S. Grundtvigs Poetiske Skrifter, bind 1-9, København.

US I-X = Holger Begtrup (udg.) (1904-09), Nik. Fred. Sev. Grundtvigs Udvalgte Skrifter, bind 1-10, København.

$V U \mathrm{I}-\mathrm{X}=$ Georg Christensen og Hal Koch (udg.) (1940-49), N. F. S. Grundtvigs Vaerker i Udvalg, bind 1-10, København.

\section{Litteraturliste}

\section{Værker af Grundtvig}

Balslev, Th. et al. (1944-64), Grundtvigs Sang-Vark. Samlet Udgave, bind 1-6, København.

Begtrup, Holger (udg.) (1904-09), Nik. Fred. Sev. Grundtvigs Udvalgte Skrifter, bind 1-10, København.

- (1924), N. F. S. Grundtvigs Vartovs-Pradikener 1839-1860, København.

Christensen, Georg og Grundtvig, Stener (udg.) (1926), Breve fra og til N. F. S. Grundtvig, bind 2, København.

Grundtvig, N. F. S., (1810), "Hvi er Herrens Ord forsvundet af Hans Hus" i US II, 8-20.

— (1844), "Albert Thorvaldsen" i US IX, 9-13.

— (1844), "Mellem Grave" i VU VIII, 230-231.

_ (1844), "Brage-Snak" i US VIII, 493-788.

— (1845), "Til min egen Meta" i US IX, 42-44.

(1848), "Albert Thorvaldsen" i Danskeren I, 417-423.

— (1855-61), "Den Christelige Børnelærdom" i US IX, 329-595.

Grundtvig, Svend et al. (udg.) (1885), N. F. S. Grundtvigs Poetiske Skrifter, bind 6, København.

Johansen, Steen (udg.) (1948-54), Bibliografi over N. F. S. Grundtvigs skrifter, bind 1-4, København. 


\section{Værker af andre forfattere}

Bojsen-Møller, Anna (udg.) (1999), Eline Boisens Erindringer, bind 13, København.

Brun, H (1882), Biskop N. F. S. Grundtvigs Levnetsløb udførligst fortalt 1839, Bind 1-2, København.

Ertner, Jørgen (1997), "Et ord af Guds søn: Salmen 'Sov sødt, Barnlille' og dens tilblivelse”, Grundtvig Studier 1997, bind 48, København, 185-211.

Holm, Jette (2005), "Breve til og fra Grundtvig, marts - juni 1844", Grundtvig-Studier 2005, København, s. $72 \mathrm{ff}$.

Køster, Kristian (1868), Det kirkelige Vennemøde i Kjøbenhavn Sept. 1868, København.

Ludvigsen, Valdemar Leth (1977), "Herrens bøn 'Fadervor",, i For Sammenhoengens Skyld, Århus, 158-185.

Madsen, J. Kr. (1871), Det kirkelige Vennemøde i Kjøbenhavn $i$ Pintseugen, København.

Malling, Anders (1962-78), Dansk Salmehistorie, bind 1-8, København.

Pontoppidan, Morten (1917), Gamle Stier. En Bønnebog for eenfoldige Kristne, København.

Rønning F. (1913), N. F. S. Grundtvig, bind 4, København.

Rørdam, H. F. (udg.) (1892), Peter Rørdam. Blade af hans Levnedsløb og Brevvexling, Del 1 og 2, København.

Roskilde Konvents Psalmebog (1855), Psalmebog til Kirke- og HuusAndagt.

Thodberg, Christian (1989), Syn og sang. Poesi og teologi hos Grundtvig, København.

\section{Noter}

Denne artikel er en bearbejdet udgave af et foredrag holdt ved Center for Grundtvigstudier, Aarhus Universitet, den 28. februar 2005, et forkortet uddrag af min kommentar til udgaven af Grundtvig Pradikener $i$ Vartov, bind 8, der forventelig udkommer i foråret 2006.

1 Se Danskeren nr. 27, onsdag den 20. september 1848, 417-423, jf. US IX, 9-13.

2 Som hedning hørte han til "lysalferne", der stod Gud nær. Som menneske stod han højt både personligt og i sin kunst, og Grundtvig anfører, at kirkehistorikeren Euseb fortæller, at han i Paneas ved Jordan har set en billedstøtte af Kristus, der bliver tilbedt af en hedensk kvinde, nemlig den blodsottige kvinde (Matt 9,20) (strofe 13), der minder om Kristus-statuen i Vor Frue Kirke og Thorvaldsens Dåbsengel foran. Thorvaldsen kendte altså Kristus, og egentlig har han ligeså stor ret til kristennavnet som visse andre (strofe 10): 
Gjaldt det om Aren mellem os i Nord,

Hvo turde dig vel nægte Christen-Navnet!

Gjaldt det om Eren overalt paa Jord,

Saa god en Christen vorder længe savnet,

Ei blot i Mylren under Himmel-Tag,

Men midt i Præste-, Bispe-, Pave-Lag!

At Grundtvigs sygdom var velkendt i København, fremgår også af prædikantlisterne i Adresseavisen. Grundtvigs teologiske tilhængere sluttede op om ham og ydede ham praktisk hjælp ved at vikariere for ham i Vartov Kirke i sygdomsperioden ( $\mathrm{h}=$ højmessen, $\mathrm{a}=$ aftensang):

Mariæ bebudelsesdag (24/3 1844): Ludvig Helweg (a)

Palmesøndag (31/3 1844): Fr. Hammerich (h), Anton Christiani (a)

Skærtorsdag (4/4 1844): Ludvig Helweg (a)

Langfredag (5/4 1844): Fr. Ditlev Møller (a)

Påskedag (7/4 1844): C. J. Brandt (a)

2. påskedag (8/4 1844): Fr. Hammerich (h), C. C. Boisen (a)

2. s. e. påske (21/4 1844): Mads Melbye (a)

3. s. e. påske (28/4 1844): Ludvig Helweg (a)

Store Bededag (3/5 1844): Fr. Hammerich (h), P. O. Boisen (a)

4. s. e. påske (5/5 1844): C. C. Boisen (h), C. J. Brandt (a)

5. s. e. påske (12/5 1844): Fr. Hammerich (h), C. C. Boisen (h)

Kristi himmelfartsdag (16/5 1844): P. J. Boesen (h), A. Christiani (a)

6. s. e. påske (19/5 1844): Fr. Hammerich (h), Fr. D. Møller (a)

Pinsedag (26/5 1844): Johan Henrik Spur (a)

2. pinsedag (27/5 1844): Fr. Hammerich (a)

Trinitatis søndag (2/6 1844): P. J. Boesen (a) (?)

Det drejer sig hovedsageligt om teologer, der havde mindre embeder ved forskellige institutioner i København, men som i den følgende tid hørte til den gruppe af præster, der hørte til den grundtvigske bevægelse. Der kan som nævnt ikke være tvivl om, at en af de nævnte har fået forfald ved aftensangen 1 . s. e. påske, der blev aflyst.

4 Grundtvigs farvel må have virket overraskende på hans menighed. Det var et stærkt vidnesbyrd om hans selvfølelse. Mere indlysende var Grundtvigs afsked med sine tilhængere ved vennemødet i 1871, hvor Grundtvig ved mødet i Kasino 31. maj 1871 indledte med at sige: "Se jeg døer, men Herren skal være med Eder! Disse Patriarken Jakobs Ord til hans store Børneflok i den gamle Pagts Dage har mere end en Gang ligget mig paa Tunge midt i den store Forsamling til et saadant Vennemøde som det nærværende" (Madsen 1871, 38).

5 Om hele rejsen, se Johansen 1950, II, 242-43 og Rønning 1913, IV, 51 ff. og 77 .

6 Brev til Gunni Busck af 2. maj 1844. Fasc. 460, jf. brev nr. 8 i Holm (2005).

7 Jf. brevet 30. april 1844 til P. A. Fenger ( $B G$ II, 392 f.), hvori han skitserer sin rejseplan, men han nævner ikke i brevet ét ord om sin sygdom, og noget synes at tyde på, at den først giver sig tydelige fysiske udslag nogle dage senere. Om besøget i Magleby hører man kun om 
stilfærdige hændelser, bl.a. en udflugt til Møens Klint. Besøget satte sig spor i det afsluttende digt i den trykte udgave af Brage-Snak, der blev udgivet senere på året (se US VIII, 786-87). Grundtvigs besøg i Magleby Præstegård omtales også af Eline Boisen (Bojsen-Møller 1999, II, 539 f.); hun kritiserer skarpt Grundtvigs holdning til sin kone.

Salmen i det følgende gengives ikke efter Grundtvigs brev fra august 1844, men fra den tidligst kendte version fasc. 383 .

KB, N.B.D. 2. rk. N. F. S. Grundtvig til pastor Joh. Ferd. Fenger $28 / 5$ 1844.

14 Khvn 28de Mai 1844.

Kiære Ven!

Tak for Deres kiærlige Modtagelse og venlige Besøg, og Tak for Tonerne, De har været med at kalde frem til Vuggevisen, som (Sp) Smaapigerne igaar sang for mig, uden at jeg savnede Andet end "MadikeTunge" der i Engle-Mund passer bedst til os daarlige Efterlignere af Ham, der sagde "jeg er en Orm og ikke en Mand," og er desuden en gammel Medicin for min gamle Adam. Hils nu Kora mange Gange med Tak for hendes gamle Godhed for mig og min Sang, og spørg, om hun ikke kunde falde paa en smuk Melodi til Pindse-Sangen

Talsmand, som paa Jorderige

Med et Suk kan Alt udsige,

ikke fordi jeg foretrækker den umaadelig, men fordi jeg seer, at [P.] Hjorth og Flere giør det og finder, den kan ogsaa være god, naar den faaer Gænger.

Vuggevisen har ellers faaet et Indskud som 2det Vers:

2

Med Fingrene sande

Slaae Kors for din Pande!

Med Gudsbarnets Røst

Slaae Kors for dit Bryst!

Saa kan ingen Djævel dig giæste;

Saa skal om din Daab,

Med Saligheds Haab,

Sig Mindet i Barmen rodfæste.

Hos mig slutter den ogsaa først saaledes:

5

Da alle de Kiøbte,

I Jesu Navn Døbte,

Som Striden har stridt,

Som Døden har lidt,

Gik ind til den evige Hvile,

Istemme saa lydt 
Halleluja nyt,

At Englene tie og smile.

6

Sov sødt, Barnlille!

Lig rolig og stille

Og nyn paa det Navn,

Med Fylden i Favn,

Al Jorden til Salighed givet!

Nyn: Jesus er min,

Saa faur og saa fiin,

Min Jesus er Lyset og Livet!

Min Kone løb fra mig i Roskilde, og vi Andre, Drengene og jeg, kom ikke længer end til Frederiksborg, hvor Nattergalen sang saa deilig, at jeg fandt, Sommeren, som jeg reiste efter, var nu fuldelig naaet og gav indtil videre Helsingør en god Dag.

Vi overraskede altsaa min Kone Torsdag Eftermiddag, men hun overraskede os igien med det Budskab, at, efter Dronningens Villie og med Kongens Vidende skulde vi ligge paa Landet i Sommer! Lille Tuborg er nu valgt til Residens, og det morer mig blandt Andet at "Gammel Vartou" ligger lige over for. Hils Rikke, at jeg kommer igien, og naar De seer Venner som Deres Broder, Ingemann, og [P. C.] Kierkegaard, da hils ogsaa dem paa det Kiærligste fra Deres N. F. S. Grundtvig.

Jf. Thodberg 1989, 181-187 (De Levendes Land (1824)).

Fengernes Julehefte 1845 (jf. Malling 1964, IV, 406). I øvrigt henvises i det følgende til Malling, når det gælder mindre ændringer.

Jf. DDS03 293,7; se iøvrigt Ludvigsen 1977 ("For sammenhængens skyld"), 158-185.

Ertner (1997, 193-194) forsvarer med stor omhu det modsatte standpunkt. Psalmebog til Kirke- og Huus-Andagt, nr. 545,9.

Malling 1962-78, bind IV, 409-411. I grundtvigske kredse brugtes også en kortere form (stroferne 1-2 og 7) som decideret dåbssalme. En svagere strofe, der brugtes i nogle udgaver i Festsalmer, udgik helt:

Dit Hoved du bukke!

Din Sjæl sig neddukke,

For aldrig at døe,

I Livskilde-Sø,

Hvor Rosen paa Rand ikke falmer!

Ved Daaben opgroer

Af Paradis-Jord

De deilige Evigheds-Palmer.

Ordet "Faa" må opfattes som dativ, altså "for få".

Jf. Balles Døbeformular 1783. Jeg vedgår villigt, at den bestandige og helt ulogiske sammenstilling i salmerne af på den ene side "favnen" og på den anden side "bøn" og "Fadervor" kalder på en forklaring, og mit forsøg i den retning var den første inspiration til afhandlingen En glemt 
dimension $i$ Grundtvigs salmer. Bundetheden til dåbsritualet (1969) (Thodberg 1989,7-119).

23 Det er i kort form indholdet i den i forrige note nævnte afhandling, som der i det følgende henvises til.

24 Mens "Fadervor" og "Guds favn" kun sjældent kædes sammen i salmerne i Sangværkets første tre bind, bliver sammenkædningen hyppig i Sangværkets fjerde og femte bind, dvs. fra og med 1844 (GSV I-VI).

25 Den refereres i Pontoppidan (1917, 53-54) og den norske cand.theol. H. Brun (1883, 734-736). Det er den sidste kilde, der her er lagt til grund.

26 Jf. forrige note.

27 "Saligheds håb" eller "herligheds håb" (Kol 1,27c) bliver ofte i salmerne et kodeord for "Kristus i os" og Fadervor, dvs. den bøn, der bedt i Jesu navn gør os til søskende sammen med Ham:

Paa vor Vugge, ved vor Daab,

Det er Faddergaven,

Deri Herlighedens Haab

Hæver sig af Graven;

Bedes kan ei Fadervor

Uden ægte Børnekaar,

Arveret til Riget!

(GSV V 175,2)

Se i øvrigt Thodberg 1989, 68-88.

28 I DDS03 hedder det "De råbe, de sjunge:" ligesom i den allerførste version af strofe 4 (se ovenfor, s. 49). Såvidt det vides, kan det ikke siges, hvorfor man har grebet så langt tilbage i traditionen. Når alt kommer til stykket, udtrykker "Guds-Englene sjunge:" tydeligere, hvem "De" er!

29 "Da" ændres til "Og" i 1. tillæg til Roskilde Konvents Psalmebog (nr. 594), vist nok en forringelse, idet "Da" i strofe 5 står parallelt med det indledende "Da" i strofe 6; de understreger begge steder Guds opfyldelse af bønnen.

30 I versionen fra omkring 1850 ændres "tie" til "lytte".

31 Jf. Jørgen Ertners omhyggelige og overbevisende argumentation (1997, 190-192). 